\title{
A New Cytotoxic Naphthoquinone and Other Chemical Constituents of Sinningia reitzii
}

\author{
Adson S. Silva, ${ }^{a}$ Magali S. Amorim, ${ }^{a}$ Mariana M. Fonseca, ${ }^{b}$ Marcos J. Salvador, ${ }^{b}$ \\ Eduardo L. de Sáa and Maria Élida A. Stefanello ${ }^{\circledR * a}$
}

\author{
${ }^{a}$ Departamento de Química, Universidade Federal do Paraná, 81530-900 Curitiba-PR, Brazil \\ ${ }^{b}$ Departamento de Biologia Vegetal, Instituto de Biologia, Universidade Estadual de Campinas, \\ 13083-970 Campinas-SP, Brazil
}

\begin{abstract}
Phytochemical study of Sinningia reitzii (Gesneriaceae) led to the isolation of three new naphtoquinones, 6,7-dimethoxydunnione, 7-hydroxy-6-methoxydunnione, and 5-hydroxy6,7-dimethoxydunnione from the tubers, together with four known compounds, 7-hydroxydunnione, 8-hydroxydunnione, 5-hydroxy-6,7-dimethoxy- $\alpha$-dunnione, and 8-hydroxydeydrodunnione. Aerial parts furnished five known compounds, 5-hydroxy-6,7-dimethoxydunniol, 6,8-dihydroxy-7-methoxy2-O-methyldunniol, loureirin $\mathrm{B}$, jacaranone, and methyl 4-hydroxyphenylacetate. Compounds 8-hydroxydunnione, 5-hydroxy-6,7-dimethoxy- $\alpha$-dunnione, 8-hydroxydeydrodunnione, 5-hydroxy-6,7-dimethoxydunniol and 6,8-dihydroxy-7-methoxy-2-O-methyldunniol had been previously reported in the tubers of $S$. reitzii. Density functional theory was used to assign the absolute configuration of compounds 6,7-dimethoxydunnione, 7-hydroxy-6-methoxydunnione 5-hydroxy-6,7-dimethoxydunnione, 7-hydroxydunnione, 8-hydroxydunnione, 5-hydroxy6,7-dimethoxy- $\alpha$-dunnione. Compounds 6,7-dimethoxydunnione, 8 -hydroxydunnione, 5-hydroxy6,7-dimethoxy- $\alpha$-dunnione and 8 -hydroxydeydrodunnione were evaluated for cytotoxicity against PC3 (prostate), SKMEL 103 (melanoma), and HeLa (cervix) human cancer, and 3T3 fibroblast cell lines, using the 3-(4,5-dimethyl-2-thiazolyl)-2,5-diphenyl-2H-tetrazolium bromide (MTT) assay. Compound 6,7-dimethoxydunnione displays cytotoxic activity against all the tumor cell lines tested (half maximal inhibitory concentration, $\mathrm{IC}_{50}, 4.47-26.2 \mu \mathrm{mol} \mathrm{L}{ }^{-1}$ ), and was inactive against $3 \mathrm{~T} 3$ fibroblasts $\left(\mathrm{IC}_{50}>100 \mu \mathrm{mol} \mathrm{L}{ }^{-1}\right)$. Compounds 8-hydroxydunnione, 5-hydroxy-6,7-dimethoxy$\alpha$-dunnione and 8-hydroxydeydrodunnione were inactive against all tested cell lines.
\end{abstract}

Keywords: Gesneriaceae, Sinningia reitzii, naphthoquinones, cytotoxic activity

\section{Introduction}

The family Gesneriaceae ( 150 gen / 3000 spp) comprises herbs, lianas and shrubs, distributed in the tropics around the world. Several species are used as ornamental plants due their attractive flowers. Aeschynanthus spp. ("basket plant", "lipstick plant"), Columnea spp., Nematanthus spp. (both known as "goldfish plant"), Saintpaulia ionantha ("African violet"), and Sinningia speciosa ("gloxinia") are widely cultivated species. The chemical profile of Gesneriaceae includes flavonoids, terpenoids, phenolic glycosides, phenyl propanoids, quinones and essential oils. The production of caffeoyl phenylethanoid glycosides together with the lack of iridoids is considered characteristic of the family. ${ }^{1}$

*e-mail: elida@ufpr.br
Gesneriaceae is represented in Brazil by 28 genera and 221 species. Sinningia is a neotropical genus comprising ca. 70 species distributed from Southern Mexico to Northern Argentina. This is the major genus of Gesneriaceae in Brazil, followed by Nematanthus (32 spp) and Besleria (21 spp)., ${ }^{2,3}$

S. reitzii (Hoehne) L. E. Skog is a perennial subshrub, with numerous small tubers, endemic to Brazil, where it is found in the States of São Paulo, Paraná and Santa Catarina. ${ }^{3}$ Several Sinningia species, including $S$. reitzii, are known as "cachimbo" in Santa Catarina. ${ }^{4}$ No uses for S. reitzii were found in traditional medicine. Eight naphthoquinones were previously reported from the tubers of this plant, including one with anti-inflammatory and antinociceptive activities. ${ }^{5}$ The isolation of additional compounds from tubers, the first study of aerial parts, and the cytotoxic evaluation of four naphthoquinones are reported herein. 
Tubers of $S$. reitzii yielded three new naphthoquinones (1-3) and four known compounds (4-7), while aerial parts furnished five known compounds (8-12). All isolated compounds were analyzed by $1 \mathrm{D}$ and $2 \mathrm{D}$ nuclear magnetic resonance (NMR) spectroscopy, and the data were compared to the literature. Thus, the known compounds were identified as 7-hydroxydunnione (4), ${ }^{6}$ 8-hydroxydunnione (5), ${ }^{6}$ 5-hydroxy-6,7-dimethoxy$\alpha$-dunnione (6), ${ }^{5}$ 8-hydroxydehydrodunnione (7), ${ }^{5}$ 5-hydroxy-6,7-dimethoxydunniol (8), ${ }^{5}$ 6,8-dihydroxy7-methoxy-2-O-methyldunniol $(\mathbf{9}),{ }^{7}$ loureirin B $(\mathbf{1 0}),{ }^{8}$ jacaranone (11) ${ }^{9}$ and methyl 4-hydroxyphenylacetate $(\mathbf{1 2})^{10}$ (Figure 1). Compounds 5-9 had been previously reported in the tubers. ${ }^{5}$ The cytotoxic activity of compounds $\mathbf{1}$ and 5-7 against human tumor cell lines was evaluated.

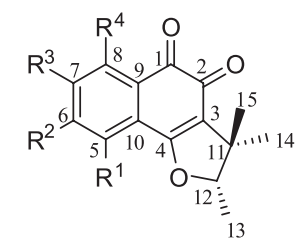

$\begin{array}{llll}\mathrm{R}^{1} & \mathrm{R}^{2} & \mathrm{R}^{3} & \mathrm{R}^{4}\end{array}$

$1 \mathrm{H}$ OMe OMe H

$2 \mathrm{H}$ OMe $\mathrm{OH} \mathrm{H}$

$3 \mathrm{OH}$ OMe $\mathrm{OMe} \mathrm{H}$

$\begin{array}{llllll}4 & \mathrm{H} & \mathrm{H} & \mathrm{OH} & \mathrm{H}\end{array}$

$\begin{array}{llllll}5 & \mathrm{H} & \mathrm{H} & \mathrm{H} & \mathrm{OH}\end{array}$<smiles>[R]C1=C(C(C)(C)C=C)C(=O)c2c([R])c([R])c(OC)c([R])c2C1=O</smiles>

$\begin{array}{llll}R^{1} & R^{2} & R^{3} & R^{4}\end{array}$

8 OH OMe $\mathrm{H} \mathrm{OH}$

$9 \mathrm{H}$ OH OH OMe

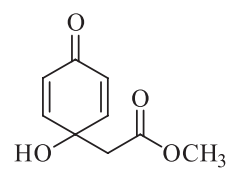

11

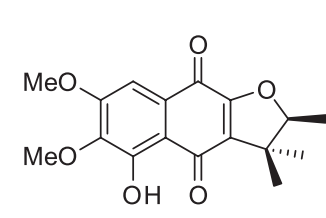

6

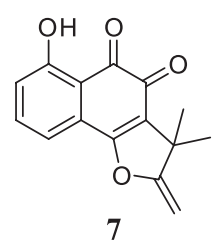

(OCH3

10

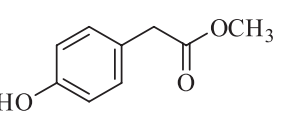

12
Figure 1. Chemical structures of the compounds 1-12.

\section{Experimental}

\section{General experimental procedures}

Optical rotations were measured in $\mathrm{CHCl}_{3}$ on a Rudolph Research polarimeter. The UV spectrum was obtained in $\mathrm{MeOH}$ on a Shimadzu UV-2401PC spectrophotometer.
Optical density $(\lambda=570 \mathrm{~nm})$ was measured using a Synergy 2 spectrophotometer (Bio-Tek). One-dimensional $\left({ }^{1} \mathrm{H}\right.$, ${ }^{13} \mathrm{C}$ ) and two-dimensional (gradient selected heteronuclear multiple bond coherence (gHMBC), gradient selected heteronuclear single quantum coherence (gHSQC)) NMR spectra were recorded on Bruker spectrometers (AC 200, Avance 400 and/or Avance 600), observing ${ }^{1} \mathrm{H}$ at 200, 400 or $600 \mathrm{MHz}$ and ${ }^{13} \mathrm{C}$ at 50,100 or $150 \mathrm{MHz} . \mathrm{CDCl}_{3}$ or $\mathrm{CD}_{3} \mathrm{OD}$ were used as solvents, and the chemical shifts are given in ppm $(\delta)$ using tetramethylsilane (TMS) as internal reference, with coupling constants $(J)$ in $\mathrm{Hz}$. High-resolution electrospray ionization mass spectrometry (HRESIMS) data were obtained on a Micromass ESI Q-TOF mass spectrometer. Geometry optimization and density functional theory calculations on the electronic structure of the compounds employed B3LYP functional having Los Alamos ECP as basis set as implemented in Gaussian09 suite program..$^{11,12}$ Theoretical optical activities were calculated after geometry optimization. ${ }^{13}$ High performance liquid chromatography (HPLC) separations were performed in a Waters apparatus equipped with photodiode array (PDA) detector, and a semi-preparative Nucleosil 100-5 $\mathrm{C}_{18}$ column $(250 \times 10 \mathrm{~mm})$. The mobile phase was acetonitrile:water 80:20 (isocratic elution), applied for $15 \mathrm{~min}$. The flow rate was $2.8 \mathrm{~mL} \mathrm{~min}^{-1}$ at room temperature. Silica gel (Merck, 230-400 mesh) was used for column chromatographic separations (CC), while precoated silica gel plates (Macherey-Nagel) were used for thin layer chromatography (TLC) and preparative TLC (PTLC). Compounds were visualized by exposure under $\mathrm{UV}_{254 / 366}$ light and spraying with 5\% (v/v) $\mathrm{H}_{2} \mathrm{SO}_{4}$ in ethanol solution, followed by heating on a hot plate.

\section{Plant material}

Specimens of Sinningia reitzii (Hoehne) L. E. Skog were collected from a natural population in Jundiaí do Sul, Paraná State, Brazil (2326 $45^{\prime \prime}$ S, 50 $0^{\circ} 15^{\prime} 33^{\prime \prime}$ W) in March 2010. The plant was identified by Clarice B. Poliquesi, who deposited a voucher specimen in the herbarium of Museu Botânico Municipal (MBM 253150). The plants were cultivated in Curitiba, Paraná State, Brazil (2526'34.85”' S, $\left.49^{\circ} 14^{\prime} 22.58^{\prime \prime} \mathrm{W}\right)$. Botanical material for phytochemical study was harvested from the cultivated plants in August 2012 (tubers, sample A) and April 2015 (aerial parts and tubers, sample B).

\section{Extraction and isolation}

Dried and powdered tubers (sample A, $30.9 \mathrm{~g}$; sample B $46.6 \mathrm{~g}$ ) were extracted with hexanes (HEX, mixture of 
isomers), $\mathrm{CH}_{2} \mathrm{Cl}_{2}$, EtOAc and EtOH, successively ( $50 \mathrm{~mL}$ of each solvent for $10 \mathrm{~g}$ of material, three times each solvent) at room temperature. The solvent was removed at reduced pressure using a rotatory evaporator, yielding the extracts in $\operatorname{HEX}(\mathrm{A}=0.30 \mathrm{~g} ; \mathrm{B}=0.34 \mathrm{~g}), \mathrm{CH}_{2} \mathrm{Cl}_{2}(\mathrm{~A}=0.27 \mathrm{~g}$; $\mathrm{B}=0.28 \mathrm{~g})$; EtOAc $(\mathrm{A}=0.25 \mathrm{~g} ; \mathrm{B}=0.26 \mathrm{~g})$, and $\mathrm{EtOH}$ $(\mathrm{A}=1.03 \mathrm{~g} ; \mathrm{B}=1.22 \mathrm{~g})$. Extracts from sample A were kept at $-4{ }^{\circ} \mathrm{C}$ until fractionation. After TLC analyses, HEX and $\mathrm{CH}_{2} \mathrm{Cl}_{2}$ extracts from both samples were pooled, and an aliquot $(0.14 \mathrm{~g})$ was reserved. The remaining extract (1.05 g) was submitted to CC (HEX:EtOAc 95:5, 9:1, 8:2 and $0: 1)$ to give 20 fractions $\left(\mathrm{F}_{1-20}\right)$ after TLC analyses. Compounds 7 (10.2 mg), $6(10.9 \mathrm{mg})$, and $\mathbf{5}(13.6 \mathrm{mg})$ were obtained from $\mathrm{F}_{4}(127.7 \mathrm{mg}$, eluted with HEX:EtOAc 9:1) after PTLC $\left(\mathrm{CH}_{2} \mathrm{Cl}_{2}: \mathrm{MeOH}\right.$ 99:1). Fraction $\mathrm{F}_{16}(44.0 \mathrm{mg}$, eluted with HEX:EtOAc 8:2) yielded $\mathbf{1}$ (6.6 mg) after PTLC (HEX:EtOAc 1:1). Fraction $\mathrm{F}_{19}(163.1 \mathrm{mg}$ ) was submitted to $\mathrm{CC}\left(\mathrm{CH}_{2} \mathrm{Cl}_{2}\right.$ :EtOAc 95:5, 9:1, 8:2, 7:3 and 0:1) to give eight subfractions $\left(\mathrm{F}_{19.1-8}\right)$ after TLC analyses. Subfraction $\mathrm{F}_{19.2}$ (12.3 mg, eluted with $\mathrm{CH}_{2} \mathrm{Cl}_{2}:$ EtOAc 95:5) yielded $\mathbf{1}$ $(1.7 \mathrm{mg})$ and $\mathbf{3}(6.1 \mathrm{mg})$ after PTLC $\left(\mathrm{CH}_{2} \mathrm{Cl}_{2}:\right.$ EtOAc 95:5). Subfraction $\mathrm{F}_{19.3}$ (eluted with $\mathrm{CH}_{2} \mathrm{Cl}_{2}: \mathrm{EtOAc}$ 95:5) yielded $\mathbf{3}$ (4.3 mg). Subfraction $\mathrm{F}_{19.6}$ (eluted with $\mathrm{CH}_{2} \mathrm{Cl}_{2}$ :EtOAc 9:1) yielded $2(5.2 \mathrm{mg})$. Subfraction $\mathrm{F}_{19.7}(15.9 \mathrm{mg}$, eluted with $\mathrm{CH}_{2} \mathrm{Cl}_{2}$ :EtOAc 8:2), yielded 4 (3.7 mg) after preparative TLC (HEX:EtOAc 1:1).

Dried and powdered aerial parts $(29.6 \mathrm{~g})$ were extracted with $\mathrm{HEX}, \mathrm{CH}_{2} \mathrm{Cl}_{2}$, EtOAc and EtOH as was described for the tubers, yielding the respective extracts after solvent removal. The HEX extract $(0.162 \mathrm{~g})$ was submitted to $\mathrm{CC}$ (HEX: $\mathrm{CH}_{2} \mathrm{Cl}_{2}$ 8:2, 1:1 and 0:1) to give eight fractions $\left(\mathrm{FH}_{1-8}\right)$, after TLC analyses. Fraction $\mathrm{FH}_{4}$ (20.3 mg, eluted with HEX: $\left.\mathrm{CH}_{2} \mathrm{Cl}_{2} 1: 1\right)$ yielded $8(2.6 \mathrm{mg}$ ), after PTLC $\left(\mathrm{CH}_{2} \mathrm{Cl}_{2}\right)$. Fraction $\mathrm{FH}_{6}(10.3 \mathrm{mg}$, eluted with $\left.\mathrm{CH}_{2} \mathrm{Cl}_{2}\right)$ yielded $9(0.8 \mathrm{mg})$, after PTLC $\left(\mathrm{CH}_{2} \mathrm{Cl}_{2}\right.$ :acetone 95:5). The $\mathrm{CH}_{2} \mathrm{Cl}_{2}$ extract $(0.209 \mathrm{~g})$ was submitted to $\mathrm{CC}$ $\left(\mathrm{CH}_{2} \mathrm{Cl}_{2}\right.$ :EtOAc 1:0, 99:1, 8:2, 0:1) to give five fractions $\left(\mathrm{FD}_{1-5}\right)$. Fraction $\mathrm{FD}_{2}\left(27.9 \mathrm{~g}\right.$, eluted with $\left.\mathrm{CH}_{2} \mathrm{Cl}_{2}\right)$ yielded 9 $(3.2 \mathrm{mg})$ after repeated PTLC $\left(\mathrm{CH}_{2} \mathrm{Cl}_{2}\right)$. Fraction $\mathrm{FD}_{4}$ (24.9 mg, eluted with $\mathrm{CH}_{2} \mathrm{Cl}_{2}$ :EtOAC 8:2) yielded $\mathbf{1 0}$ (2.1 mg) after PTLC $\left(\mathrm{CH}_{2} \mathrm{Cl}_{2}: \mathrm{MeOH} 99: 1\right)$. The EtOAC extract $(0.240 \mathrm{~g})$ was submitted to $\mathrm{CC}\left(\mathrm{CH}_{2} \mathrm{Cl}_{2}: \mathrm{MeOH}\right.$ 99:1, 95:5, 9:1, 0:1) to give eight fractions $\left(\mathrm{FA}_{1-8}\right)$. Fraction $\mathrm{FA}_{4}$ (47.4 mg, eluted with $\mathrm{CH}_{2} \mathrm{Cl}_{2}: \mathrm{MeOH}$ 99:1) yielded a mixture $(8.5 \mathrm{mg}$ ), which was separated by HPLC to give $\mathbf{1 1}$ $\left(\mathrm{t}_{\mathrm{R}} 7.8 \mathrm{~min}, 2.7 \mathrm{mg}\right)$ and $\mathbf{1 2}\left(\mathrm{t}_{\mathrm{R}} 8.1 \mathrm{~min}, 3.2 \mathrm{mg}\right)$.

\section{Cytotoxic activity assay}

The cytotoxic activity of compounds $\mathbf{1}$ and 5-7 was evaluated against the human tumor cell lines PC-3 (prostate), SKMEL 103 (melanoma), HeLa (epitheloid cervix carcinoma), and the non-cancer cell line 3T3 (fibroblast), all from the American Type Culture Collection (ATCC). The assays were done as previously described. ${ }^{14,15}$ The cells were distributed in 96 -well plates $(100 \mu \mathrm{L}$ cells per well), and exposed to various concentrations of the tested compounds $\left(0.25,2.5,25.0\right.$ and $\left.250 \mu \mathrm{g} \mathrm{mL}^{-1}\right)$ in dimethyl sulfoxide (DMSO) $(0.1 \%)$ at $37{ }^{\circ} \mathrm{C}$, with $5 \%$ of $\mathrm{CO}_{2}$, for $48 \mathrm{~h}$. The final concentration of DMSO did not affect cell viability. Doxorubicin $(0.025,0.25,2.5$ and $25 \mu \mathrm{g} \mathrm{mL}^{-1}$ ) was used as the positive control. The proliferation of tumor cells was quantified by the ability of living cells to reduce the yellow dye 3-(4,5-dimethyl2-thiazolyl)-2,5-diphenyl-2H-tetrazolium bromide (MTT) to a blue formazan product. At the end of $48 \mathrm{~h}$ incubation, the medium was replaced by fresh medium containing $0.5 \mathrm{mg} \mathrm{mL}^{-1}$ of MTT. Three hours later, the formazan product was dissolved in DMSO, and the optical density was measured by spectrophotometry at $570 \mathrm{~nm}$. The experiments were carried at least in triplicate and the concentration needed to achieve 50\% inhibition of cell

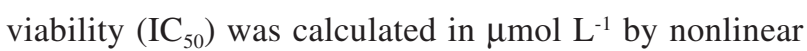
regression using the GraphPad program. ${ }^{16}$

\section{6,7-Dimethoxydunnione (1)}

Dark purple solid; experimental $[\alpha]_{\mathrm{D}}^{20}-228(c$ 0.27, $\left.\mathrm{CHCl}_{3}\right)$, calculated $[\alpha]_{\mathrm{D}}-268$; UV-Vis $(\mathrm{MeOH})$ $\lambda_{\max } / \mathrm{nm}(\log \varepsilon) 214$ (3.99), 280 (3.95), 332 (3.32); IR (KBr) $v_{\max } / \mathrm{cm}^{-1} 2922$ and $2840(\mathrm{C}-\mathrm{H}), 1640(\mathrm{C}=\mathrm{O}), 1600,1560$, and $1520(\mathrm{C}=\mathrm{C}$, aromatic), 1270, 1161 and $1022(\mathrm{C}-\mathrm{O})$; for ${ }^{1} \mathrm{H}$ and ${ }^{13} \mathrm{C}$ NMR data, see Table 1; HRESIMS $\mathrm{m} / \mathrm{z}$, calcd. for $\mathrm{C}_{17} \mathrm{H}_{19} \mathrm{O}_{5}[\mathrm{M}+\mathrm{H}]^{+}$: 303.12299, found: 303.12349.

\section{7-Hydroxy-6-methoxydunnione (2)}

Purple solid; experimental $[\alpha]_{\mathrm{D}}^{20}-79\left(c 1.0, \mathrm{CHCl}_{3}\right)$, calculated $[\alpha]_{\mathrm{D}}-224$; UV-Vis $(\mathrm{MeOH}) \lambda_{\max } / \mathrm{nm}(\log \varepsilon)$ 211 (4.07), 277 (4.01), 283 (4.02), 316 (3.62); IR (KBr) $v_{\max } / \mathrm{cm}^{-1} 3539(\mathrm{OH}$, free), $3431(\mathrm{OH}$, associated $), 2916$ and $2848(\mathrm{C}-\mathrm{H}), 1629(\mathrm{C}=\mathrm{O}), 1607,1576$, and 1529 (C-C, aromatic), $1274(\mathrm{C}-\mathrm{O})$; for ${ }^{1} \mathrm{H}$ and ${ }^{13} \mathrm{C}$ NMR data, see Table 1; HRESIMS $m / z$, calcd. for $\mathrm{C}_{16} \mathrm{H}_{17} \mathrm{O}_{5}[\mathrm{M}+\mathrm{H}]^{+}$: 289.10808, found: 289.10760 .

\section{5-Hydroxy-6,7-dimethoxydunnione (3)}

Dark red solid; experimental $[\alpha]_{\mathrm{D}}^{20}-146$ (c 0.21 , $\mathrm{CHCl}_{3}$ ), calculated $[\alpha]_{\mathrm{D}}-440$; UV-Vis $(\mathrm{MeOH}) \lambda_{\max } / \mathrm{nm}$ ( $\log \varepsilon) 212$ (4.30), 267 (4.03), 300 (3.91); IR (KBr) $v_{\max } / \mathrm{cm}^{-1} 3421(\mathrm{OH}), 2958,2927$ and $2848(\mathrm{C}-\mathrm{H}), 1643$ $(\mathrm{C}=\mathrm{O}), 1604$ and $1585(\mathrm{C}=\mathrm{C}$, aromatic), $1260(\mathrm{C}-\mathrm{O})$; for ${ }^{1} \mathrm{H}$ and ${ }^{13} \mathrm{C}$ NMR data, see Table 2; HRESIMS $\mathrm{m} / \mathrm{z}$, calcd. for $\mathrm{C}_{17} \mathrm{H}_{19} \mathrm{O}_{6}[\mathrm{M}+\mathrm{H}]^{+}:$319.11847, found: 319.11816 . 


\section{Results and Discussion}

Compound 1 was isolated as dark purple solid. HRESIMS in positive mode displays an ion at $\mathrm{m} / z 303.12299$ $[\mathrm{M}+\mathrm{H}]^{+}$, indicating the molecular formula $\mathrm{C}_{17} \mathrm{H}_{18} \mathrm{O}_{5}$, which is consistent with nine indices of hydrogen deficiency. In the ${ }^{1} \mathrm{H}$ NMR data, signals of two para-coupled aromatic protons, $\left(\delta_{\mathrm{H}} 7.07\right.$ and 7.55$)$, two singlets of methoxy groups $\left(\delta_{\mathrm{H}} 3.97\right.$ and 4.01), and the typical signals of a 2,3-dihydro2,3,3-trimethylfuran group (quartet at $\delta_{\mathrm{H}} 4.63$, two singlets at $\delta_{\mathrm{H}} 1.25$ and 1.44 , and a doublet at $\delta_{\mathrm{H}} 1.47$ ) were observed (Table 1). The ${ }^{13} \mathrm{C}$ NMR data showed 17 peaks, including two of carbonyl groups at $\delta_{\mathrm{C}} 175.8$ and 180.5 . These data indicate a 1,2-naphthoquinone type dunnione. ${ }^{6}$ Analysis of HSQC and HMBC spectra confirmed the structure $\mathbf{1}$ through the following cross-peaks: $\mathrm{H}-5\left(\delta_{\mathrm{H}} 7.07\right)$ with carbons at $\delta_{\mathrm{C}} 125.0(\mathrm{C}-9), 151.5(\mathrm{C}-7)$, and $168.2(\mathrm{C}-4)$; H-8 $\left(\delta_{\mathrm{H}} 7.55\right)$ with carbons at $\delta_{\mathrm{C}} 122.5(\mathrm{C}-10), 153.9$ $(\mathrm{C}-6)$, and $180.5(\mathrm{C}-1)$; and $\mathrm{H}-14\left(\delta_{\mathrm{H}} 1.25\right)$ with carbons at $\delta_{\mathrm{C}} 25.8(\mathrm{C}-15), 44.1(\mathrm{C}-11), 92.9(\mathrm{C}-12)$, and 121.4 (C-3) (Table 1). Therefore, compound $\mathbf{1}$ was identified as 6,7-dimethoxydunnione (Figure 1).

Compound 2 was isolated as purple solid and has the molecular formula $\mathrm{C}_{16} \mathrm{H}_{16} \mathrm{O}_{5}$, corresponding to nine indices of hydrogen deficiency, which was deduced from an ion at $m / z 289.10808[\mathrm{M}+\mathrm{H}]^{+}$in HRESIMS. The
${ }^{1} \mathrm{H}$ NMR data of $\mathbf{2}$ (Table 1) were very similar to those of compound 1, showing signals for two aromatic protons in para relationship $\left(\delta_{\mathrm{H}} 7.07\right.$ and 7.59), one singlet of a methoxy group $\left(\delta_{\mathrm{H}} 4.03\right)$, and the signals for a 2,3-dihydro2,3,3-trimethylfuran group. In the HMBC spectrum the methoxy group $\left(\delta_{\mathrm{H}} 4.03\right)$ and $\mathrm{H}-8\left(\delta_{\mathrm{H}} 7.59\right)$ showed cross-peaks with a carbon at $\delta_{\mathrm{C}} 151.1$, which must be C-6. These and remaining correlations in the HSQC and HMBC spectra (Table 1) led to identification of $\mathbf{2}$ as 7-hydroxy6-methoxydunnione (Figure 1).

Compound 3, a dark red solid, had the molecular formula $\mathrm{C}_{17} \mathrm{H}_{18} \mathrm{O}_{6}$, with nine indices of hydrogen deficiency, as deduced from an ion at $\mathrm{m} / z 319.1184[\mathrm{M}+\mathrm{H}]^{+}$in the HRESIMS. The ${ }^{1} \mathrm{H}$ NMR data (Table 2) showed signals for one hydroxy group $\left(\delta_{\mathrm{H}} 7.68\right)$, one aromatic proton $\left(\delta_{\mathrm{H}} 7.36\right)$, two methoxy groups $\left(\delta_{\mathrm{H}} 3.96\right.$ and 3.97$)$, and the signals for a 2,3-dihydro-2,3,3-trimethylfuran group. The ${ }^{13} \mathrm{C}$ NMR spectrum showed 17 signals, including three that were typical of C-1 $\left(\delta_{\mathrm{C}} 180.5\right), \mathrm{C}-2\left(\delta_{\mathrm{C}} 175.3\right)$, and C-4 $\left(\delta_{\mathrm{C}} 168.1\right)$ in the dunnione framework. ${ }^{6}$ Analysis of HSQC and HMBC data (Table 2) led to the structure 3 (Figure 1). The aromatic proton $\left(\delta_{\mathrm{H}} 7.36\right)$ was located in $\mathrm{C}-8$ due to cross-peaks of this signal in the HMBC spectrum with C-1 $\left(\delta_{\mathrm{C}} 180.5\right), \mathrm{C}-6\left(\delta_{\mathrm{C}} 142.3\right)$, and C-10 $\left(\delta_{\mathrm{C}} 106.9\right)$. On the other hand, the position of hydroxy group in C-5 was determined from cross-peaks of the signal at $\delta_{\mathrm{H}} 7.69$ with

Table 1. NMR data $\left(\mathrm{CDCl}_{3}\right)$ for the compounds $\mathbf{1}(600 \mathrm{MHz})$ and $2(400 \mathrm{MHz})$

\begin{tabular}{|c|c|c|c|c|c|c|}
\hline \multirow[t]{2}{*}{ Position } & \multicolumn{3}{|c|}{1} & \multicolumn{3}{|c|}{2} \\
\hline & $\delta_{\mathrm{H}}(J$ in $\mathrm{Hz})$ & $\delta_{\mathrm{C}}$ & HMBC & $\delta_{\mathrm{H}}(J$ in $\mathrm{Hz})$ & $\delta_{\mathrm{C}}$ & HMBC \\
\hline 1 & & 180.5 & & & 180.5 & \\
\hline 2 & & 175.8 & & & 175.8 & \\
\hline 3 & & 121.4 & & & 121.4 & \\
\hline 4 & & 168.2 & & & 168.3 & \\
\hline 5 & $7.07(1 \mathrm{H}, \mathrm{s})$ & 106.7 & $4,7,9$ & $7.07(1 \mathrm{H}, \mathrm{s})$ & 106.5 & $4,7,9$ \\
\hline 6 & & 153.9 & & & 151.1 & \\
\hline 7 & & 151.5 & & & 148.5 & \\
\hline 8 & $7.55(1 \mathrm{H}, \mathrm{s})$ & 111.9 & $1,6,10$ & $7.59(1 \mathrm{H}, \mathrm{s})$ & 116.2 & $1,6,10$ \\
\hline 9 & & 125.0 & & & 125.8 & \\
\hline 10 & & 122.5 & & & 121.8 & \\
\hline 11 & & 44.1 & & & 44.1 & \\
\hline 12 & $4.63(1 \mathrm{H}, \mathrm{q}, 6.6)$ & 92.9 & 14,15 & $4.62(1 \mathrm{H}, \mathrm{q}, 6.7)$ & 92.8 & 14,15 \\
\hline 13 & $1.47(3 \mathrm{H}, \mathrm{d}, 6.6)$ & 14.6 & 11,12 & $1.46(3 \mathrm{H}, \mathrm{d}, 6.7)$ & 14.6 & 11,12 \\
\hline 14 & $1.25(3 \mathrm{H}, \mathrm{s})$ & 20.4 & $3,11,12,15$ & $1.25(3 \mathrm{H}, \mathrm{s})$ & 20.4 & $3,11,12,15$ \\
\hline 15 & $1.44(3 \mathrm{H}, \mathrm{s})$ & 25.8 & $3,11,12,14$ & $1.43(3 \mathrm{H}, \mathrm{s})$ & 25.8 & $3,11,12,14$ \\
\hline $6-\mathrm{OCH}_{3}$ & $4.01(3 \mathrm{H}, \mathrm{s})$ & 56.5 & 6 & $4.03(3 \mathrm{H}, \mathrm{s})$ & 56.6 & 6 \\
\hline $7-\mathrm{OCH}_{3}$ & $3.97(3 \mathrm{H}, \mathrm{s})$ & 56.4 & & & & 7 \\
\hline
\end{tabular}

HMBC: heteronuclear multiple bond coherence. 
C-5 $\left(\delta_{\mathrm{C}} 148.9\right)$, C-6 and C-10. Therefore, compound 3 was identified as 5-hydroxy-6,7-dimethoxydunnione.

In order to determine the absolute configuration of compounds 1-6, the optical rotations were calculated for the isomers using density functional theory (DFT). The results indicate that $S$ isomers are levorotatory, in agreement with previous X-ray monocrystal diffraction studies with a dunnione derivative. ${ }^{17}$ As the experimental optical rotations of compounds 1-6 were negative, their absolute configuration was assigned as $12 S$ (Figure 1). Chiral natural products are generally biosynthesized as one pure enantiomer. However, naphthoquinones have been isolated with various optical purity degree. Compound $\mathbf{4}$ was previously isolated optically pure (optical rotation +350 ), while 5 was obtained only as racemic mixture. ${ }^{6}$ In the present work, compound $\mathbf{4}$ showed $[\alpha]_{D}-23$, indicating a mixture of enantiomers, with predominance of the levorotatory isomer (53:47). The optical purity of the remaining compounds was not experimentally determined. The high optical rotation of $1\left([\alpha]_{D}-228\right)$, near from value calculated by DFT $\left([\alpha]_{D}-268\right)$ suggest that it is enantiomerically pure. On the other hand, the optical rotations of $2\left([\alpha]_{D}-79\right)$, $\mathbf{3}\left([\alpha]_{D}-146\right), \mathbf{5}\left([\alpha]_{D}-78\right)$, and $\mathbf{6}\left([\alpha]_{D}-13\right)$ were relatively low in comparison with calculated values $\left([\alpha]_{D}>-200\right)$, suggesting that these compounds were isolated as scalemic mixtures.

Table 2. NMR data $\left(400 \mathrm{MHz}, \mathrm{CDCl}_{3}\right)$ for $\mathbf{3}$

\begin{tabular}{|c|c|c|c|}
\hline Position & $\delta_{\mathrm{H}}(\mathrm{J}$ in $\mathrm{Hz})$ & $\delta_{\mathrm{C}}$ & HMBC \\
\hline 1 & & 180.5 & \\
\hline 2 & & 175.3 & \\
\hline 3 & & 121.2 & \\
\hline 4 & & 168.1 & \\
\hline 5 & & 148.9 & \\
\hline 6 & & 142.3 & \\
\hline 7 & & 155.7 & \\
\hline 8 & $7.36(1 \mathrm{H}, \mathrm{s})$ & 108.5 & $1,6,10$ \\
\hline 9 & & 126.5 & \\
\hline 10 & & 106.9 & \\
\hline 11 & & 43.0 & \\
\hline 12 & $4.75(1 \mathrm{H}, \mathrm{q}, 6.7)$ & 94.4 & 14,15 \\
\hline 13 & $1.51(3 \mathrm{H}, \mathrm{d}, 6.7)$ & 14.7 & 11,12 \\
\hline 14 & $1.27(3 \mathrm{H}, \mathrm{s})$ & 20.3 & $3,11,12,15$ \\
\hline 15 & $1.44(3 \mathrm{H}, \mathrm{s})$ & 25.6 & $3,11,12,14$ \\
\hline $5-\mathrm{OH}$ & $7.68(1 \mathrm{H}, \mathrm{s})$ & & $5,6,10$ \\
\hline $6-\mathrm{OCH}_{3}$ & $3.97(3 \mathrm{H}, \mathrm{s})$ & 61.1 & 6 \\
\hline $7-\mathrm{OCH}_{3}$ & $3.96(3 \mathrm{H}, \mathrm{s})$ & 56.5 & 7 \\
\hline
\end{tabular}

HMBC: heteronuclear multiple bond coherence.
Considering that naphthoquinones frequently display cytotoxic activity, ${ }^{18}$ compounds $\mathbf{1}$ and 5-7, which were obtained in sufficient quantity and purity, were assayed in vitro against three human tumor cell lines (PC3, SKMel 103 and HeLa) and the 3T3 (fibroblast) cell line. Compound 1 exhibited strong cytotoxicity against HeLa and PC3 cell lines $\left(\mathrm{IC}_{50}<10 \mu \mathrm{mol} \mathrm{L} \mathrm{L}^{-1}\right)$, and a smaller activity against SKMEL $103\left(\mathrm{IC}_{50} 26.2 \mu \mathrm{mol} \mathrm{L}^{-1}\right)$. Compound 1 was more active against HeLa cells $\left(\mathrm{IC}_{50} 4.47 \mu \mathrm{mol} \mathrm{L}{ }^{-1}\right)$ than the standard drug doxorubicin $\left(\mathrm{IC}_{50} 14.2 \mu \mathrm{mol} \mathrm{L} \mathrm{L}^{-1}\right)$; it was also less toxic towards the non-cancer cell line $3 \mathrm{~T} 3\left(\mathrm{IC}_{50} 157 \mu \mathrm{mol} \mathrm{L}^{-1}\right)$ in comparison to doxorubicin $\left(\mathrm{IC}_{50} 27.9 \mu \mathrm{mol} \mathrm{L}-1\right)$. Compounds 5-7 were considered inactive against all tested cells since they showed $\mathrm{IC}_{50}>50 \mu \mathrm{mol} \mathrm{L}{ }^{-1}$ (Table 3 ). Strong cytotoxic activity had previously been reported for a racemic mixture of $\mathbf{5}$ against four tumor cell lines (average growth inhibition of $50 \%, \mathrm{GI}_{50} 0.54-5.2 \mu \mathrm{mol} \mathrm{L} \mathrm{L}^{-1}$ ), including HeLa cells $\left(\mathrm{GI}_{50} 1.9 \mu \mathrm{mol} \mathrm{L} \mathrm{L}^{-1}\right.$, at roughly the same compound concentrations. ${ }^{19}$ This striking difference in cytotoxicity between the two studies may be a consequence of the different methods employed for estimating cell viability. The cytotoxicity of other $\alpha$-dunnione derivatives (similar, but not identical, to compound $\mathbf{6}$ ) has also been evaluated previously, but no clear pattern of structureactivity relationship was found. ${ }^{19}$ Anti-inflammatory and antinociceptive activities were previously reported for compound 7..$^{5}$ The small number of assayed compounds does not allow generalizations about structure-activity relationship; however, a comparison of the structures of the active compound (1) to the inactive compounds (5-7) suggests that the absence of substituents in C-5 and C-8 may be important for activity.

Table 3. Cytotoxic activity of compounds 1 and 5-7

\begin{tabular}{lccccc}
\hline \multirow{2}{*}{ Cell line } & \multicolumn{5}{c}{$\left.\mathrm{IC}_{50} /(\mu \mathrm{mol} \mathrm{L})^{-1}\right)$} \\
\cline { 2 - 6 } & $\mathbf{1}$ & $\mathbf{5}$ & $\mathbf{6}$ & $\mathbf{7}$ & Doxo $^{\mathrm{a}}$ \\
\hline PC3 & 7.77 & $>969$ & $>786$ & $>972$ & 0.40 \\
SKMEL & 26.2 & $>969$ & $>786$ & $>972$ & 8.29 \\
HeLa & 4.47 & $>969$ & 398 & 972 & 14.2 \\
3T3 & 157 & $>969$ & $>786$ & 241 & 27.9 \\
\hline
\end{tabular}

Average of three analyses. The coefficients of variation obtained were $\leq 5 \%$. $\mathrm{IC}_{50}$ : half maximal inhibitory concentration; Doxo: Doxorubicin. aDoxorubicin was used as positive control.

\section{Conclusions}

Less polar extracts of $S$. reitzii are characterized by the presence of several prenylated naphthoquinones, mainly dunnione-type. This compound class has been previously 
reported in other Sinningia species, such as S. allagophylla, ${ }^{20}$ S. canescens,${ }^{21}$ S. leucotricha,${ }^{21}$ and S. hatschbachii, ${ }^{22}$ and can be considered as typical of Sinningia. Many biological activities are associated with naphthoquinones, including antibacterial, cytotoxic, antitumoral, insecticidal, and anti-inflammatory. ${ }^{18}$ Accordingly, a new naphthoquinone, reported in this work, displays selective cytotoxic activity against three human tumor cell lines.

\section{Supplementary Information}

Supplementary information (spectra of compounds 1-12, and data of known compounds 4-12) is available free of charge at http://jbcs.sbq.org.br as PDF file.

\section{Acknowledgments}

We are grateful to CAPES (Finance Code 001), FAEPEX-UNICAMP, FAPESP (processes: 15/03726-8 and 17/03598-5), and CNPq for scholarships and financial support, and to Clarisse B. Poliquesi, from Museu Botânico Municipal de Curitiba, for the collection and identification of the plant material.

\section{References}

1. Zaitlin, D.; AoB Plants 2012, pls039, DOI: 10.1093/aobpla/ pls039; Verdan, M. H.; Stefanello, M. E. A.; Chem. Biodiversity 2012, 9, 2701; Lorenzi, H.; Souza, H. M.; Plantas Ornamentais do Brasil: Arbustivas, Herbáceas e Trepadeiras, $3^{\mathrm{a}}$ ed.; Instituto Plantarum: Nova Odessa, Brasil, 2003; Jensen, S. R.; Phytochemistry 1996, 43, 777.

2. Ferreira, G. E.; Ferreira, P. M. A.; Chautems, A.; Waechter, J. L.; Flora 2016, 222, 86.

3. Araujo, A. O.; Chautems, A.; Ferreira, A. In Flora do Brasil 2020 em Construção, Jardim Botânico do Rio de Janeiro, available at http://floradobrasil.jbrj.gov.br/reflora/floradobrasil/ FB119, accessed in December 2018.

4. Reitz, R.; Sellowia 1959, 11, 9.

5. Soares, A. S.; Barbosa, F. L.; Rüdiger, A. L.; Hughes, D. L.; Salvador, M. J.; Zampronio, A. R.; Stefanello, M. E. A.; J. Nat. Prod. 2017, 80, 1837.

6. Inoue, K.; Ueda, S.; Nayeshiro, H.; Inouye, H.; Phytochemistry 1983, 22, 737 .

7. Zhong, Y.-J.; Wen, Q.-F.; Li, C.-Y.; Su, X.-H.; Yuan, Z.-P.; Li, Y.-F.; Helv. Chim. Acta 2013, 96, 1750.

8. Meksuriyen, D.; Cordell, G. A.; J. Nat. Prod. 1988, 51, 1129.
9. Massaoka, M. H.; Matsuo, A. L.; Figueiredo, C. R.; Farias, C. F.; Girola, N.; Arruda, D. C.; Scutti, J. A. B.; Romoff, P.; Favero, O. A.; Ferreira, M. J. P.; Lago, J. H. G.; Travassos, L. R.; PloS One 2012, e38698.

10. Fleming, P.; O'Shea, D. F.; J. Am. Chem. Soc. 2011, 133, 1698.

11. Hay, P. J.; Wadt, W. R.; J. Chem. Phys. 1985, 82, 270.

12. Frisch, M. J.; Trucks, G. W.; Schlegel, H. B.; Scuseria, G. E.; Robb, M. A.; Cheeseman, J. R.; Scalmani, G.; Barone, V.; Petersson, G. A.; Nakatsuji, H.; Li, X.; Caricato, M.; Marenich, A.; Bloino, J.; Janesko, B. G.; Gomperts, R.; Mennucci, B.; Hratchian, H. P.; Ortiz, J. V.; Izmaylov, A. F.; Sonnenberg, J. L.; Williams-Young, D.; Ding, F.; Lipparini, F.; Egidi, F.; Goings, J.; Peng, B.; Petrone, A.; Henderson, T.; Ranasinghe, D.; Zakrzewski, V. G.; Gao, J.; Rega, N.; Zheng, G.; Liang, W.; Hada, M.; Ehara, M.; Toyota, K.; Fukuda, R.; Hasegawa, J.; Ishida, M.; Nakajima, T.; Honda, Y.; Kitao, O.; Nakai, H.; Vreven, T.; Throssell, K.; Montgomery Jr., J. A.; Peralta, J. E. Ogliaro, F.; Bearpark, M.; Heyd, J. J.; Brothers, E.; Kudin, K. N.; Staroverov, V. N.; Keith, T.; Kobayashi, R.; Normand, J.; Raghavachari, K.; Rendell, A.; Burant, J. C.; Iyengar, J.; Tomasi, S. S.; Cossi, M.; Millam, J. M.; Klene, M.; Adamo, C.; Cammi, R.; Ochterski, J. W.; Martin, R. L.; Morokuma, K.; Farkas, O.; Foresman, J. B.; Fox, D. J.; Gaussian 09, Revision C01; Gaussian Inc., Wallingford, CT, 2016.

13. Pedersen, T. B.; Hansen, A. E.; Chem. Phys. Lett. 1995, $246,1$.

14. Mosmann, T.; J. Immunol. Methods 1983, 16, 55.

15. Pascoal, A. C. R. F.; Lourenço, C. C.; Sodek, L.; Tamashiro, J. Y.; Franchi Jr., G. C.; Nowill, A. E.; Stefanello, M. E. A.; Salvador, M. J.; J. Essent. Oil Res. 2011, 23, 34.

16. GraphPad Prism, version 5.00; Intuitive Software for Science, San Diego, 2007.

17. Cooke, R. G.; Ghisalberti, E. L.; Johnson, B. L.; Raston, C. L.; Skelton, B. W.; White, A. H.; Aust. J. Chem. 2006, 59, 925.

18. Babula, P.; Adams, V.; Havel, L.; Kizek, R.; Curr. Pharm. Anal. 2009, 5, 47; López, J.; Cruz, F.; Alcaraz, Y.; Delgado, F.; Vásquez, M. A.; Med. Chem. Res. 2015, 24, 3599.

19. Duchowicz, P. R.; Bennardi, D. O.; Bacelo, D. E.; Bonifazi, E. L.; Rios-Luci, C.; Padrón, J. M.; Burton, G.; Misico, R. I.; Eur. J. Med. Chem. 2014, 77, 176; Sheridan, H.; Nestor, C.; O'Driscoll, L.; Hooke, I.; J. Nat. Prod. 2011, 74, 82.

20. Scharf, D. R.; Verdan, M. H.; Ribeiro, M. A.; Simionatto, E. L.; Sá, E. L.; Salvador, M. J.; Barison, A.; Stefanello, M. E. A.; J. Nat. Prod. 2016, 79, 792.

21. Verdan, M. H.; Scharf, D. R.; Barison, A.; Salvador, M. J.; Stefanello, M. E. A.; Phytochem. Lett. 2017, 22, 205.

22. Amorim, M. S.; Serain, A. F.; Salvador, M. J.; Stefanello, M. E. A.; Nat. Prod. Commun. 2017, 12, 1763.

Submitted: December 9, 2018 Published: April 4, 2019 